\title{
Effect of breadmaking process on mycotoxin content in white and whole wheat breads
}

\author{
Casiane Salete Tibola $^{\mathbf{1}}$ (D) | Martha Zavariz de Miranda ${ }^{\mathbf{1}}$ | Flávia Fernandes Paiva ${ }^{2}$ | \\ José Mauricio Cunha Fernandes $^{1}$ | Eliana Maria Guarienti ${ }^{1}$ | Marcio Nicolau ${ }^{1}$
}

\author{
${ }^{1}$ Embrapa Trigo, Passo Fundo, RS, Brazil \\ ${ }^{2}$ Department of Agroindustrial Science \\ and Technology, Federal University of \\ Pelotas, Capão do Leão, RS, Brazil

\section{Correspondence} \\ Casiane Salete Tibola, Embrapa Trigo, \\ Rodovia BR-285, km 294, C.P. 3081, \\ Passo Fundo, RS, Brazil 99001-970. \\ Email: casiane.tibola@embrapa.br \\ Funding information \\ Brazilian Agricultural Research \\ Corporation (Embrapa); National Council \\ for Scientific and Technological \\ Development (CNPq), Grant/Award \\ Number: 473177/2014-5
}

\begin{abstract}
Background and objectives: Fusarium graminearum may reduce the wheat flour yield, technological quality, and breadmaking performance. The objective was to evaluate the effect of breadmaking on the mycotoxin content in white and whole wheat breads to obtain information about the safety of wheat products. The wheat samples were contaminated via the addition of Fusarium-damaged kernels to produce different levels of deoxynivalenol (DON), ranging from $<500$ to $>5,000 \mu \mathrm{g} / \mathrm{kg}$.
\end{abstract}

Findings: Because of the breadmaking process, a significant reduction in the DON concentration was observed in both the white and whole wheat breads at the upper DON levels $(>2,000 \mu \mathrm{g} / \mathrm{kg})$ compared with the flours. The DON reduction was $49 \%$ and $39 \%$, respectively, in whole and white breads, compared with the original flours. ZON was only detected in the two higher levels of DON in the whole wheat flour (mean $33.1 \mu \mathrm{g} / \mathrm{kg}$ ) and in the two whole wheat breads (mean $42.4 \mu \mathrm{g} / \mathrm{kg}$ ).

Conclusions: The breadmaking process can be a complementary strategy to reduce the mycotoxin content in wheat products.

Significance and novelty: These results are important for wheat supply chain to meet the legislation requirements and to produce safer foods.

\section{K E Y W O R D S}

deoxynivalenol, food safety, mycotoxin contamination, wheat

\section{1 | INTRODUCTION}

Wheat is the main source of nutrients for the world population. Most wheat is converted into wheat flour for human consumption, that is, bakery products, such as bread, pasta, noodles, and cakes (Pacin, Bovier, Cano, Taglieri, \& Pezzani, 2010; Šramkova, Gregová, \& Šturdík, 2009). Wheat bread provides more nutrients to the world community than any other single food source (Peña, 2002).

Most of the wheat growing area in Brazil is located in the Southern region in the Paraná (56\%) and Rio Grande do Sul (33\%) states. The current domestic production is unable to supply the national demand of approximately 10.3 million tons annually (USDA, 2017). In Southern Brazil, Fusarium head blight (FHB) is caused by the Fusarium graminearum species complex, which produces deoxynivalenol (DON) and zearalenone (ZON) mycotoxins (Del Ponte et al., 2015). DON is the most important mycotoxin because of its widespread occurrence and high concentration in wheat grains. DON disrupts normal cell function, which results in protein synthesis inhibition and affects cell signaling, differentiation, and proliferation (Terzi, Tumino, Stanca, \& Morcia, 2014; Vidal, Marín, Morales, Ramos, \& Sanchis, 2014). ZON causes a hyperestrogenic syndrome 
and reproductive dysfunction (Iqbal, Asi, Jinap, \& Rashid, 2014).

Ingestion of contaminated food is a major route for exposure to many contaminants, including mycotoxins (Monaci, Garbetta, De Angelis, Visconti, \& Minervini, 2015). Exposition studies have shown the high level of exposure of humans to DON, and high percentages of the population exceed the tolerable daily intake, which is mostly attributed to the consumption of contaminated, wheat-derived products (Vidal, Sanchis, Ramos, \& Marín, 2016). In Brazil, Savi et al. (2016) reported that $17 \%$ of whole wheat bread and $10 \%$ of salted cracker products were contaminated with DON at mean levels of 437 and $624 \mu \mathrm{g} / \mathrm{kg}$, respectively. In another study, cracker-type biscuit samples from Southern Brazil were analyzed, and 78\% of the samples had DON levels ranging from 377 to $5,295 \mu \mathrm{g} / \mathrm{kg}$, and $22 \%$ were contaminated at levels higher than those allowed by regulation (Souza, Caldas, Primel, \& Furlong, 2015).

The thermostability of some mycotoxins allows them to withstand most food processes (Vidal, Sanchis, Ramos, \& Marín, 2015). Deoxynivalenol is stable at $120^{\circ} \mathrm{C}$ and moderately stable at $180^{\circ} \mathrm{C}$, and it is damaged at $210^{\circ} \mathrm{C}$ after $40 \mathrm{~min}$ (Kamimura, 1989). Zearalenone is a chemically stable compound with a melting point of $164-165^{\circ} \mathrm{C}$ (EFSA, 2004).

Determining the effects of processing on mycotoxin levels is crucial to estimate consumer exposure. The main factors that affect the fate of mycotoxins during food processing are the food matrix, $\mathrm{pH}$, moisture content, processing temperature, natural or spiked contamination, and concentration of the toxin (Samar, Neira, Resnik, \& Pacin, 2001; Wu \& Wang, 2015; Zhang \& Wang, 2014). Specifically, the mycotoxin stability in the baking process is based on the temperature, time, dough moisture content, type, and quality of the flour and recipe (Milani \& Maleki, 2014).

The baking quality (parameters/baking ingredients) and DON stability have been extensively investigated, but the results are conflicting. The inconsistencies may exist because of the following factors: different scales (laboratorial or industrial), the size of the baked products, the use of enzymes, and the baking time and temperature (Vidal et al., 2016).

Zhang and Wang (2014) reported that the DON levels approximately doubled when mixed and fermented doughs were processed into Chinese steamed bread. Another study found that the DON levels in baked bread were significantly higher than those in flour and increased 1.63- to 1.95-fold (Zhang \& Wang, 2015). The breadmaking process resulted in low, insignificant reduction rates compared with the initial levels $(p>0.05)$ for DON in both common bread and bread with the addition of $15 \%$ wheat germ (Giménez, Blesa, Herrera, \& Ariño, 2014). Cakes baked at 160,180 , and $200^{\circ} \mathrm{C}$ had a significantly lower DON concentration compared with the concentration at the beginning of the process $(p<0.05)$, but the reduction achieved at $140^{\circ} \mathrm{C}$ was not significant (Vidal et al., 2015). Bergamini et al. (2010) reported a significant reduction in DON levels in bread compared with wheat flour.

The objective of this study was to evaluate the effect of breadmaking on the mycotoxin content in white and whole wheat breads made with Fusarium contaminated wheat flour to obtain information about the safety of wheat products.

\section{MATERIALS AND METHODS}

\section{1 | Sampling characterization}

Wheat samples of 6,000 g each, harvested in 2013 crop season from Southern Brazil, were used in this study. Different ratios of wheat kernels naturally contaminated with Fusarium mycotoxins, and sound kernels were used in this work. The amount of DON content was selected using trial error basis and confirmed by ELISA. The wheat sample was divided in four subsamples that were contaminated with different amounts of FHB wheat symptomatic grains. The final deoxynivalenol content in the subsamples was (a) $<500$, (b) 500-1,999, (c) 2,000-4,999, and (d) $>5,000 \mu \mathrm{g} / \mathrm{kg}$. Detailed information about the contamination process is described in Tibola, Fernandes, Guarienti, and Nicolau (2015).

In all subsamples, moisture and protein contents were determined by Near Infrared Reflectance Spectroscopy (NIR instrument FOSS XDS - RCA, Hoganas, Sweden). The protein content ranged from $12.3 \%$ to $13.5 \%$ and moisture content ranged from $14.6 \%$ to $15.8 \%$. The yield of flour obtained from each subsample in the milling process was $43.9 \%, 42.0 \%, 42.6 \%$, and $40.1 \%$, respectively, from level 1 to level 4 of initial DON contamination.

Two milling processes were used to obtain the wheat flour: first, a Laboratory Mill 3100 (Perten Instruments, Huddinge, Sweden) was used to obtain the whole grain flour used to bake the whole wheat bread. The Quadrumat Senior Brabender experimental mill (Brabender, Duisburg, Germany) was used to obtain the white wheat flour for traditional white bread processing.

\section{2 | Baking procedures}

Breads were baked without fat using the straight-dough breadmaking process based on the bread method used in breeding programs (IRAM, 1996). The ingredients were (Oro, Miranda, Tatsch, \& De Francisco, 2012) wheat 
flour $(100 \%)$, sucrose $(1.7 \%)$, instant active dry yeast (4\%), sodium chloride $(0.7 \%)$, and deionized water (in a sufficient amount to stabilize a $14 \%$ moisture content). The ingredients were mixed in one operation for $6 \mathrm{~min}$, until their complete hydration and optimum dough development, in a Brabender farinograph mixer $(300 \mathrm{~g})$. The dough was kneaded, manually sheeted (Atlas 150 \& Pastabike, Marcato S.P.A., Italy), divided into $100 \mathrm{~g}$ dough pieces, with three replicates, and placed into a rectangular mold $(4 \times 8 \times 3 \mathrm{~cm})$. The dough was then fermented for $40 \mathrm{~min}$ in a proofing cabinet (Gelopar, Brazil) at $30^{\circ} \mathrm{C}$ with a $100 \%$ relative humidity. Subsequently, the dough was baked in an electric oven (Fischer, Brazil) for $35 \mathrm{~min}$ at $180^{\circ} \mathrm{C}$.

After cooling (at least $1 \mathrm{hr}$ at room temperature), the bread was weighed. The mean bread loaf weight was 85.63 and $85.86 \mathrm{~g}$ for white and whole wheat breads, respectively.

The breads were dried in an oven at $50^{\circ} \mathrm{C}$ for $24 \mathrm{hrs}$, milled in a laboratory blender, and mixed before $60 \mathrm{~g}$ samples were taken for the mycotoxin analysis. The crushed dry bread was homogenized prior to the mycotoxin analysis. The collected set of samples was sent to a reference laboratory (Samitec, Santa Maria/RS) for mycotoxin quantification.

\section{3 | Mycotoxin analysis}

The mycotoxin content was determined in flour and in bread on an "as is" basis, that is, the concentration determined without any correction for moisture content.

The DON and ZON contents in the breads were determined using ultra high-performance liquid chromatography in tandem with triple quadrupole mass spectrometry (UHPLC-MS/MS). The extraction, clarification, and derivatization methodologies were fully automatized and developed and validated in house using the method described by Varga et al. (2012). The laboratory obtained the following limits of quantification and recovery: for DON $200 \mu \mathrm{g} / \mathrm{kg}$ and $80 \%$, respectively; for $\mathrm{ZON}, 20 \mu \mathrm{g} / \mathrm{kg}$ and $85 \%$, respectively. The relative standard deviation (RSD) for DON and ZON was $4 \%$ and $4.75 \%$, respectively. The DON-acetylated derivatives (15-ADON and 3-ADON) and nivalenol were not detected in any of the whole wheat and white flours.

\section{4 | Statistical analysis}

Statistical analyses were performed using R Software 3.3.3 (R Development Core Team, 2017). The independent $t$ test was used to determine the differences in the DON and ZON contents, in each contaminated subsample. The significance was set at $p<0.05$.

\section{3 | RESULTS}

\section{1 | Deoxynivalenol}

After the breadmaking process, a reduction in the DON content was observed at the higher contamination levels $(>2,000 \mu \mathrm{g} / \mathrm{kg})$ in the white and whole wheat breads compared with the original flours (Table 1).

Overall, in the whole wheat bread, the DON reduction was $49 \%$ compared with the original flour. Similarly, in white bread, the DON content decreased significantly in the two higher contamination levels ranging from 2,000 to $>5,000 \mu \mathrm{g} / \mathrm{kg}$. The overall DON reduction in white breads was 39\%, when compared to white flours.

When the four contamination levels were individually analyzed, the DON content in the whole wheat bread was lower than that in the whole wheat flour for the levels ranging from $500-1,999 \mu \mathrm{g} / \mathrm{kg}$ to higher than $5,000 \mu \mathrm{g} / \mathrm{kg}$.

\subsection{Zearalenone}

The zearalenone (ZON) content slightly increased in the breads compared with the original content in the flours, but the difference was not statistically significant. ZON was only detected in the two higher levels of the whole wheat flour (mean $33.1 \mu \mathrm{g} / \mathrm{kg}$ and standard deviation $4.2 \mu \mathrm{g} / \mathrm{kg}$ ) and the two whole wheat breads (mean $42.4 \mu \mathrm{g} / \mathrm{kg}$ and standard deviation $15.1 \mu \mathrm{g} / \mathrm{kg}$ ) (Figure 1). In the white flour fraction, ZON was not detected in any of the analyzed subsamples.

\section{4 | DISCUSSION}

Deoxynivalenol is one of the most frequent wheat contaminants worldwide, and it poses a risk to human and animal health due to its wide range of adverse effects (Vidal et al., 2016). Therefore, studying the factors that affect DON degradation and contribute to the food safety is important. Flour is the fraction that contributes the most to the daily intake of DON in Southern Brazil, representing 89.6\% of the provisional maximum tolerable daily intake (Savi et al., 2016). According to Santos et al. (2013), the average intake of the inhabitants of Londrina City in northern Paraná State (Brazil) was $0.79 \mu \mathrm{g} / \mathrm{kg}$ body weight for bread and $0.35 \mu \mathrm{g} / \mathrm{kg}$ body weight for pasta. The total estimated daily intake of DON was $1.13 \mu \mathrm{g} / \mathrm{kg}$, which is above the provisional tolerable daily maximum intake of $1 \mu \mathrm{g} / \mathrm{kg}$ body weight, established by FAO/WHO Expert Committee (JECFA, 2001).

In our study, the DON content was reduced in both breads made from whole wheat and white flours for the higher levels of DON contamination $(>2,000 \mu \mathrm{g} / \mathrm{kg})$. In the 
TA B LE 1 Concentration of DON in the original flours and in the white and whole wheat breads

\begin{tabular}{lllllllll}
$\begin{array}{l}\text { Levels of DON } \\
\text { contamination in } \\
\text { wheat grains } \\
(\boldsymbol{\mu g} / \mathbf{k g})\end{array}$ & $\begin{array}{l}\text { Mean whole } \\
\text { wheat flour } \\
(\boldsymbol{\mu g} / \mathbf{k g})\end{array}$ & $\begin{array}{l}\text { Standard } \\
\text { deviation } \\
(\boldsymbol{\mu g} / \mathbf{k g})\end{array}$ & $\begin{array}{l}\text { Mean whole wheat } \\
\text { bread }(\boldsymbol{\mu g} / \mathbf{k g})\end{array}$ & $\begin{array}{l}\text { Standard } \\
\text { deviation } \\
(\boldsymbol{\mu g} / \mathbf{k g})\end{array}$ & $\begin{array}{l}\text { Mean white } \\
\mathbf{f l o u r}(\boldsymbol{\mu g} / \mathbf{k g})\end{array}$ & $\begin{array}{l}\text { Standard } \\
\text { deviation } \\
(\boldsymbol{\mu g} / \mathbf{k g})\end{array}$ & $\begin{array}{l}\text { Mean white } \\
\mathbf{b r e a d}(\boldsymbol{\mu g} / \mathbf{k g})\end{array}$ & $\begin{array}{l}\text { Standard } \\
\text { deviation } \\
(\boldsymbol{\mu g} / \mathbf{k g})\end{array}$ \\
\hline$<500$ & 498.75 & 29.31 & $293.00^{\mathrm{a}}$ & - & 265.25 & 46.96 & ND \\
\hline $500-1,999$ & 746.50 & 70.71 & $293.00^{*}$ & 132.51 & 495.75 & 36.11 & $305.00^{\mathrm{a}}$ & - \\
\hline $2,000-4,999$ & $2,747.50$ & 140.80 & $1,072.33^{*}$ & 422.55 & $2,157.50$ & 79.32 & $297.33^{*}$ & 25.89 \\
\hline$>5,000$ & $5,985.00$ & 260.58 & $2,593.33^{*}$ & $1,071.56$ & $5,360.00$ & 331.36 & $1,486.67^{*}$ & 77.67 \\
\hline
\end{tabular}

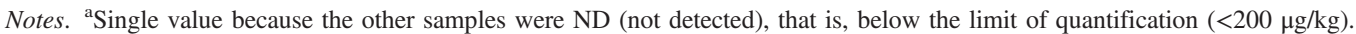

*Significantly different value in columns $(p<0.05)$.

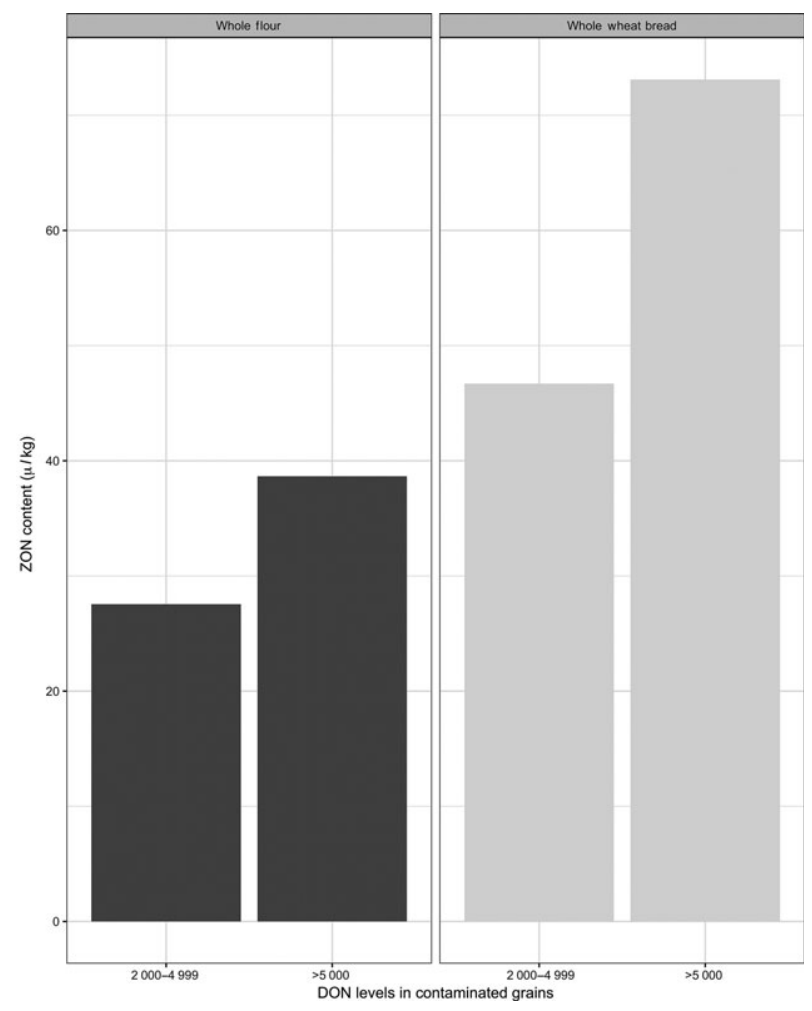

F IG URE 1 Zearalenone levels in whole wheat flour and whole wheat bread with different DON gradients

lower DON contamination levels $(<500$ and $500-1,999 \mu \mathrm{g} /$ $\mathrm{kg}$ ), a reduction in the DON content was observed, and some breads had levels below $200 \mu \mathrm{g} / \mathrm{kg}$ (not detected). Although these results are desirable for wheat product safety, it was not possible to compare the data statistically.

The main factors involved in diminishing DON content during bread making process are temperature, time, loaf size, ingredients, and experimental scale (industrial/laboratorial) (Vidal et al., 2015, 2016). In our study, the DON reduction during the baking process $\left(180^{\circ} \mathrm{C}\right.$ for $\left.35 \mathrm{~min}\right)$ could be explained by the small size of loaves (100 g), which favored temperature distribution through the inner layers and consequently affected the DON stability.
Kostelanska et al. (2011) reported DON reduction of 13\%, during the baking process $\left(240{ }^{\circ} \mathrm{C}\right.$ for $\left.14 \mathrm{~min}\right)$, of breads with $80 \mathrm{~g}$ each. Noticeably, the DON reduction occurred in the bread crust that was exposed to higher temperatures. There were no changes in the DON content in crumbs when the baking temperature did not exceed $85^{\circ} \mathrm{C}$. Similarly, Vidal et al. (2014) reported that DON degradation took place exclusively in the crust, with loaf size of $260 \mathrm{~g}$. Such degradation was not enough to detect a significant decrease in DON content in the whole sample. In contrast, De Angelis, Monaci, Pascale, and Visconti (2013) reported that DON levels markedly increased upon baking at $200^{\circ} \mathrm{C}$ for $55 \mathrm{~min}$, with breads of approximately $500 \mathrm{~g}$ weight.

Our results were in accordance with previous studies (Milani \& Maleki, 2014; Pacin et al., 2010; Scudamore, Hazel, Patel, \& Scriven, 2009; Vidal et al., 2015). The mean reduction in DON between flour and products was 42.3\% for French bread and 58.3\% for Vienna bread (Pacin et al., 2010). Milani and Maleki (2014) reported that baking regular bread, cookies, and biscuits provided a variable DON reduction, from $24 \%$ to $71 \%$ in bread and $35 \%$ in cookies and biscuits. The mean concentrations of DON in white bread and wholemeal bread were reduced by about $35 \%$ and $39 \%$, respectively, than the concentration in the flour (Scudamore et al., 2009). In the baking process, the relative DON reduction after $40 \mathrm{~min}$ varied from $29 \%$ at $140^{\circ} \mathrm{C}$ to $81 \%$ at $200^{\circ} \mathrm{C}$ (Vidal et al., 2015).

In the whole wheat bread, the observed relative reduction was $41 \%$ for the lowest level $(<500 \mu \mathrm{g} / \mathrm{kg})$ and $57 \%$ for the highest contamination level $(>5,000 \mu \mathrm{g} / \mathrm{kg})$. In the white breads, the highest DON reduction (86\%) was obtained for the level ranging from 2,000 to $4,999 \mu \mathrm{g} / \mathrm{kg}$. Our results differed from the study conducted by Vidal et al. (2016). They concluded that the initial DON concentration affected the DON reduction, when the initial DON concentration was higher, a greater reduction was obtained.

The levels of DON in the whole wheat bread were higher compared with the white bread. This difference was not due to the effect of the baking process and was derived 
instead from the different DON levels in the original flours. Similarly, Vidal et al. (2014) concluded that the DON concentration during breadmaking was not significantly affected by the bran content of the bread. Scudamore (2008) described a DON reduction of approximately 50\% from the flour to the white bread due to the dilution effect from the increased moisture content. For whole meal bread, the DON concentration ranged from 28 to $71 \mu \mathrm{g} / \mathrm{kg}$ compared to whole flour $58-125 \mu \mathrm{g} / \mathrm{kg}$. The author stated that based on the DON levels required by European legislation, the relative reduction in the DON content via processing wheat into bread (from 1,250 to $500 \mu \mathrm{g} / \mathrm{kg}$ ) would allow white bread but not whole wheat bread to meet the DON level requirements.

In Brazil, the upper limits of DON established for whole wheat and white flour are 1,250 and $1,000 \mu \mathrm{g} / \mathrm{kg}$, respectively (ANVISA, 2017). The maximum levels allowed for final bakery products are the same as that for the white flour. The Brazilian regulations also limits the ZON levels in cereals and by-products; in 2017, the upper levels for whole wheat and white flour were set at 200 and $100 \mu \mathrm{g} / \mathrm{kg}$, respectively (ANVISA, 2017). Considering these levels, only the flours and breads with the two lower levels of DON contamination in our study would meet the mycotoxin regulation.

In line with previous studies, we did not find that the breadmaking process had any effect on the ZON content. Cano-Sancho, Sanchis, Ramos, and Marín (2013) did not see an effect on the ZON content after baking (at $200^{\circ} \mathrm{C}$ for $20 \mathrm{~min}$ ) or fermentation with Saccharomyces cerevisiae.

Further studies involving a higher number of samples, different baking conditions, and refined analysis will be important to explain the factors that affect the mycotoxin degradation in wheat products.

\section{5 | CONCLUSIONS}

This study focused on evaluating the effects of the breadmaking process on wheat mycotoxin content. The breadmaking process reduced the DON content in breads compared to the original whole wheat and white flours. Therefore, the baking process can be a complementary strategy to reduce dietary exposure to DON. Otherwise, ZON reduction is unlikely to occur in the breadmaking process.

\section{ACKNOWLEDGMENTS}

We are grateful for the financial support for this study provided by the Brazilian Agricultural Research Corporation (Embrapa) and National Council for Scientific and Technological Development (CNPq) - 473177/2014-5.

\section{ORCID}

Casiane Salete Tibola (D) http://orcid.org/0000-0003-20368163

\section{REFERENCES}

ANVISA (2017). RDC Resolution n. 138, Regulation on tolerable maximum levels (LMT) for deoxynivalenol in food. Brasília, DF: Agência Nacional de Vigilância Sanitária.

Bergamini, E., Catellani, D., Dall'Asta, C., Galaverna, G., Dossena, A., Marchelli, R., \& Suman, M. (2010). Fate of Fusarium mycotoxins in the cereal product supply chain: The deoxynivalenol (DON) case within industrial bread-making technology. Food Additives and Contaminants Part A, 27, 677-687. https://doi.org/ 10.1080/19440041003660117

Cano-Sancho, G., Sanchis, V., Ramos, A. J., \& Marín, S. (2013). Effect of food processing on exposure assessment studies with mycotoxins. Food Additives and Contaminants Part A, 30, 867875. https://doi.org/10.1080/19440049.2013.793824

De Angelis, E., Monaci, L., Pascale, M., \& Visconti, A. (2013). Fate of deoxynivalenol, T-2 and HT-2 toxins and their glucoside conjugates from flour to bread: An investigation by high-performance liquid chromatography high-resolution mass spectrometry. Food Additives and Contaminants Part A, 30, 345-355. https://doi.org/ 10.1080/19440049.2012.740776

Del Ponte, E. M., Spolti, P., Ward, T. J., Gomes, L. G., Nicolli, C. P., Kuhnem, P. R., ... Tessmann, D. J. (2015). Regional and field-specific factors affect the composition of Fusarium head blight pathogens in subtropical no-till wheat agroecosystem of Brazil. Phytopathology, 105, 246-254. https://doi.org/10.1094/ PHYTO-04-14-0102-R

EFSA (2004). European Food Safety Authority. Opinion of the scientific panel on contaminants in the food chain on a request from the commission related to zearalenone as undesirable substance in animal feed. EFSA Journal, 89, 1-35.

Giménez, I., Blesa, J., Herrera, M., \& Ariño, A. (2014). Effects of bread making and wheat germ addition on the natural deoxynivalenol content in bread. Toxins, 6, 394-401. https://doi.org/10. 3390/toxins6010394

Iqbal, S. Z., Asi, M. R., Jinap, S., \& Rashid, U. (2014). Detection of aflatoxins and zearalenone contamination in wheat derived products. Food Control, 35, 223-226. https://doi.org/10.1016/j.foodc ont.2013.06.048

IRAM (1996). Norma IRAM 15858-1. Cereales. Ensayo de panificación experimental. Método para ser usado en programas de mejoramiento de trigo. Buenos Aires, Argentina: Instituto Argentino de Racionalización de Materiales.

JECFA (2001). Safety evaluation of certain mycotoxins in food. In Meeting of the Joint FAO/WHO Expert committee on food additives, 56. Geneva, IT: WHO Food Additives Series 47.

Kamimura, H. (1989). Removal of mycotoxins during food processing. In Papers presented at the International IUPAC Symposium on Mycotoxins and Phycotoxins, 7th. P. 169. Mycotoxins and Phycotoxins' 88. No. 10. Tokyo, JP: Elsevier Science Limited.

Kostelanska, M., Dzuman, Z., Malachova, A., Capouchova, I., Prokinova, E., Skerikova, A., \& Hajslova, J. (2011). Effects of milling and baking technologies on levels of deoxynivalenol and its masked 
form deoxynivalenol-3-glucoside. Journal of Agriculture and Food Chemistry, 59, 9303-9312. https://doi.org/10.1021/jf202428f

Milani, J., \& Maleki, G. (2014). Effects of processing on mycotoxin stability in cereals. Journal of the Science of Food and Agriculture, 94, 2372-2375. https://doi.org/10.1002/jsfa.6600

Monaci, L., Garbetta, A., De Angelis, E., Visconti, A., \& Minervini, F. (2015). Assessment of toxic potential of mycotoxin contaminated bread during in vitro human digestion on human B lymphoid cell line. Toxicology Letters, 232, 106-112. https://doi.org/ 10.1016/j.toxlet.2014.09.021

Oro, T., Miranda, M. Z., Tatsch, P. O., \& De Francisco, A. (2012). Adaptation of bread-baking test in small-scale for wheat flour. In IUFoST World Congress of Food Science and Technology, 16th International Union of Food Science and Technology: Foz do Iguaçu. Retrieved from http://iufost.org.br/sites/iufost.org.br/files/ anais/07646.pdf

Pacin, A., Bovier, E. C., Cano, G., Taglieri, D., \& Pezzani, C. H. (2010). Effect of the bread making process on wheat flour contaminated by deoxynivalenol and exposure estimate. Food Control, 21, 492-495. https://doi.org/10.1016/j.foodcont.2009.07.012

Peña, R. J. (2002). Bread wheat improvement and production. In R. J. Peña (Ed.), Wheat for bread and other foods (pp. 483-542). Rome, IT: Food and Agriculture Organization of the United Nations.

R Development Core Team (2017). R: A language and environment for statistical computing. version 3.3.3. Vienna, Austria: R Foundation for Statistical Computing.

Samar, M. M., Neira, M. S., Resnik, S. L., \& Pacin, A. (2001). Effect of fermentation on naturally occurring deoxynivalenol (DON) in Argentinean bread processing technology. Food Additives and Contaminants, 11, 1004-1010. https://doi.org/10.1080/026520301 10051284

Santos, J. S., Souza, T. M., Ono, E. Y. S., Hashimoto, E. H., Bassoi, M. C., Miranda, M. Z., ... Hirooka, E. Y. (2013). Natural occurrence of deoxynivalenol in wheat from Paraná State, Brazil and estimated daily intake by wheat products. Food Chemistry, 138, 90-95. https://doi.org/10.1016/j.foodchem.2012.09.100

Savi, G. D., Piacentini, K. C., Tibola, C. S., Santos, K., Maria, G. S., \& Scussel, V. M. (2016). Deoxynivalenol in the wheat milling process and wheat-based products and daily intake estimates for the Southern Brazilian population. Food Control, 62, 231-236. https://doi.org/10.1016/j.foodcont.2015.10.029

Scudamore, K. A. (2008). Fate of Fusarium mycotoxins in the cereal industry: Recent UK studies. World Mycotoxin Journal, 1, 315323. https://doi.org/10.3920/WMJ2008.x034

Scudamore, K. A., Hazel, C. M., Patel, S., \& Scriven, F. (2009). Deoxynivalenol and other Fusarium mycotoxins in bread, cake and biscuits produced from UK-grown wheat under commercial and pilot scale conditions. Food Additives and Contaminants, 26 (08), 1191-1198. https://doi.org/10.1080/02652030902919426

Souza, T. D., Caldas, S. S., Primel, E. G., \& Furlong, E. B. (2015). Exposure to deoxynivalenol, HT-2 and T-2 toxins by consumption of wheat-based product in southern Brazil. Food Control, 50, 789-793. https://doi.org/10.1016/j.foodcont.2014.10.015
Šramkova, Z., Gregová, E., \& Šturdík, E. (2009). Chemical composition and nutritional quality of wheat grain. Acta Chimica Slovaca, 2, 115-138.

Terzi, V., Tumino, G., Stanca, A. M., \& Morcia, C. (2014). Reducing the incidence of cereal head infection and mycotoxins in small grain cereal species. Journal of Cereal Science, 59, 284-293. https://doi.org/10.1016/j.jcs.2013.10.005

Tibola, C. S., Fernandes, J. M. C., Guarienti, E. M., \& Nicolau, M. (2015). Distribution of Fusarium mycotoxins in wheat milling process. Food Control, 53, 91-95. https://doi.org/10.1016/j.foodcont.2015.01.012

USDA (2017). Grain: World markets and trade. Washington, DC: United States Department of Agriculture.

Varga, E., Glauner, T., Köppen, R., Mayer, K., Sulyok, M., Schuhmacher, R., ... Berthiller, F. (2012). Stable isotope dilution assay for the accurate determination of mycotoxins in maize by UHPLC-MS/MS. Analytical and Bioanalytical Chemistry, 402, 2675-2686. https://doi.org/10.1007/s00216-012-5757-5

Vidal, A., Marín, S., Morales, H., Ramos, A. J., \& Sanchis, V. (2014). The fate of deoxynivalenol and ochratoxin A during the breadmaking process, effects of sourdough use and bran content. Food and Chemical Toxicology, 68, 53-60. https://doi.org/10. 1016/j.fct.2014.03.006

Vidal, A., Sanchis, V., Ramos, A. J., \& Marín, S. (2015). Thermal stability and kinetics of degradation of deoxynivalenol, deoxynivalenol conjugates and ochratoxin A during baking of wheat bakery products. Food Chemistry, 178, 276-286. https://doi.org/10. 1016/j.foodchem.2015.01.098

Vidal, A., Sanchis, V., Ramos, A. J., \& Marín, S. (2016). The fate of deoxynivalenol through wheat processing to food products. Current Opinion in Food Science, 11, 34-39. https://doi.org/10.1016/ j.cofs.2016.09.001

Wu, L., \& Wang, B. (2015). Evaluation on levels and conversion profiles of DON, 3-ADON, and 15-ADON during bread making process. Food Chemistry, 185, 509-516. https://doi.org/10.1016/j.f oodchem.2015.03.082

Zhang, H., \& Wang, B. (2014). Fate of deoxynivalenol and deoxynivalenol-3-glucoside during wheat milling and Chinese steamed bread processing. Food Control, 44, 86-91. https://doi.org/10. 1016/j.foodcont.2014.03.037

Zhang, H., \& Wang, B. (2015). Fates of deoxynivalenol and deoxynivalenol-3-glucoside during bread and noodle processing. Food Control, 50, 754-757. https://doi.org/10.1016/j.foodcont.2014.10. 009

How to cite this article: Tibola CS, de Miranda MZ, Paiva FF, Fernandes JMC, Guarienti EM, Nicolau M. Effect of breadmaking process on mycotoxin content in white and whole wheat breads. Cereal Chem. 2018;95:660-665. https://doi.org/10.1002/cche.10079 